\title{
PENGETAHUAN DAN PERAN APOTEKER TENTANG DISASTER MANAGEMENT
}

Lina Dwi Setiyarini, Devita Ardina Prameswari, Rachmad Lusia, Sisca Melani Panggono, Achmad Aziz Choiri, Nailul Fithriyah, Almira Alodia, Istna Nur 'Ainul Yaqin, Gusti Ayu Manik Suartha Putri, Farah Najla, Anisa Ikrimatun Nikmah, Elida Zairina*

Fakultas Farmasi Universitas Airlangga Surabaya

Gedung Nanizar Zaman Joenoes Kampus C, J1. Mulyorejo Surabaya 60115 Indonesia

*Email: elida-z@ff.unair.ac.id

\begin{abstract}
ABSTRAK
Indonesia merupakan negara dengan wilayah pesisir yang luas dan terpanjang di dunia. Negara dengan wilayah pesisir yang luas memiliki potensi terkena bencana tinggi, khususnya bencana banjir. Banjir di kota Surabaya dapat menyebabkan penyakit seperti diare, infeksi saluran pernapasan, serta infeksi lainnya. Apoteker memiliki peran dalam manajemen bencana dalam menangani pra, selama, dan pasca bencana. Penelitian merupakan penelitian cross sectional yang dilakukan untuk mengukur pengetahuan dan peran apoteker di Kota Surabaya, pengambilan sampel dilakukan dengan non-random sampling pada apoteker yang bersedia menjadi responden. Kuesioner digunakan untuk pengambilan data dan diisi langsung oleh apoteker yang bersedia berpartisipasi. Hasil jawaban kuesioner pada masing-masing bagian akan dilakukan skoring dengan kategori baik, cukup, dan kurang. Skor kurang (0-3), cukup (4-6), dan baik (7-9) pada masing-masing pertanyaan. Hasil penelitian didapatkan bahwa responden memiliki pengetahuan yang memadai tentang peran apoteker dan kesediaan untuk menyiapkan obat dan perangkat medis jika terjadi bencana. Dari 104 apoteker yang menjadi responden, 99 orang diantaranya $(95,2 \%)$ memiliki pengetahuan yang baik tentang peran apoteker, 5 responden $(4,8 \%)$ dengan pengetahuan cukup, dan 0 responden $(0 \%)$ dengan pengetahuan kurang. Kesediaan responden untuk menyiapkan obat-obatan dan peralatan medis yang cukup jika terjadi bencana ada pada kategori baik sejumlah 43 (41,3\%), cukup sejumlah 58 (55,8\%), dan kurang sejumlah 3 (2,9\%). Responden memiliki pengetahuan yang baik tentang peran apoteker dalam penanggulangan bencana dan bersedia memberikan obat-obatan dan peralatan medis saat terjadi bencana.
\end{abstract}

Kata kunci: Pengetahuan, peran, apoteker, banjir, manajemen bencana

\begin{abstract}
Indonesia is a country with a large coastal area and the longest in the world. Countries with large coastal areas has great potential affected by a disaster, particularly flood. In Surabaya, flood can cause diseases such as diarrhea, respiratory infections, and other infections. Pharmacists have a role in disaster management including pre, during, and post disaster problems. This study was designed as a crosssectional study was conducted to measure the knowledge and role of pharmacists in the city of Surabaya, the sampling was non-random sampling on pharmacists who were willing to be respondents. The questionnaire was used to collect data and was filled in by a pharmacist who was willing. The results of the answers to the questionnaire in each section will be scored with good, enough, and less categories. Less (0-3), enough (4-6) and good (7-9) on each question. The results, it was found that the respondents had sufficient knowledge about the role of pharmacists and a willingness to provide drugs and medical devices in the event of a disaster. From 104 pharmacist, there were $99(95,2 \%)$ pharmacist who had a good knowledge about their role in disaster management, adequate knowledge $5(4,8 \%)$, and less of knowledge $0(0 \%)$. As many as $43(41,3 \%)$ respondents were willing to prepare drugs and medical devices in the event of disasters, $58(55,8 \%)$ pharmacist were quite willing and $3(2,9 \%)$ pharmacist were less willing to prepare. Most of the respondents have good profile of knowledge regarding the role of pharmacists in disaster management and were willing to provide medicines and medical devices during disasters.
\end{abstract}

Key words: Knowledge, role, pharmacist, floods, disaster management 


\section{PENDAHULUAN}

Menurut Undang-Undang No. 24 tahun 2007, bencana adalah rangkaian peristiwa yang mengancam dan mengganggu kehidupan masyarakat yang disebabkan, baik oleh faktor alam atau faktor nonalam maupun faktor manusia sehingga mengakibatkan timbulnya korban jiwa manusia, kerusakan lingkungan, kerugian harta benda, dan dampak psikologis (Undang-Undang Republik Indonesia, 2007).

Indonesia merupakan negara kepulauan dengan jumlah pulau lebih dari tujuh belas ribu pulau. Indonesia diapit oleh dua benua dan samudera yaitu Benua Asia dan Australia, serta Samudera Pasifik dan Hindia. Indonesia menduduki peringkat keempat di dunia dalam hal jumlah penduduk dengan jumlah penduduk sebesar 258,7 juta jiwa. Indonesia terletak pada daerah Ring of Fire, sehingga banyak terjadi bencana alam, seperti gempa bumi, banjir, tanah longsor, gunung meletus, dan tsunami (Martin, 2018).

Indonesia memiliki 34 provinsi, salah satunya Jawa Timur dengan ibu kota Surabaya. Kota Surabaya terletak pada tepi pantai utara Provinsi Jawa Timur. Surabaya merupakan dataran rendah dengan ketinggian 3-6 meter di atas permukaan air laut. Surabaya memiliki iklim tropis yang terdiri dari dua musim setiap tahun, yaitu musim hujan dan musim kemarau dimana saat musim hujan, Surabaya memiliki curah hujan yang tinggi sekitar bulan OktoberFebruari (500 mm) (Anonim, 2016). Banjir merupakan salah satu bencana yang umum terjadi di Indonesia, khusunya daerah perkotaan yang padat penduduk, salah satunya adalah Kota Surabaya. Surabaya merupakah salah satu daerah yang rawan terkena banjir yang diperkirakan telah mengalami kerugian besar pertahunnya (Bima dan Fariza, 2010).

Banjir dapat disebabkan oleh berbagai hal, seperti kegiatan manusia, kondisi geografis suatu wilayah, dan curah hujan yang tinggi. Kegiatan manusia dapat menyebabkan terjadinya banjir karena semakin tingginya aktivitas dan kegiatan pembangunan yang tidak sesuai kaidah untuk menjaga lingkungan akan menyebabkan ruang terbuka hijau di perkotaan semakin sempit yang akan menyebabkan terjadinya banjir. Selain itu, banjir di Indonesia juga dapat disebabkan oleh tingginya curah hujan yang biasanya terjadi pada bulan Januari hingga Februari (Rosyidie, 2013).

Meningkatnya curah hujan dapat berdampak pada terjadinya penyakit yang ditularkan melalui air (waterborne disease) dan penurunan kualitas air pada wilayah yang terdampak banjir tersebut. Penyakit yang ditularkan melalui air adalah salah satu kontributor utama beban penyakit global dan kematian (Cann et al., 2013). Air yang terkontaminasi ini dapat memicu penyakit yang menular melalui air, misalnya diare, dengan persentase dari total kasus penyakit yang ditularkan melalui air yakni $15-20 \%$, sanitasi, dan ketersediaan air yang terbatas ini dapat meningkatkan risiko terjadinya penyakit ini, khususnya pada anak-anak di negara berkembang (Pirsaheb et al., 2017).

Diare merupakan salah satu penyakit yang bila tidak ditangani dengan segera akan berakibat fatal bahkan sampai menyebabkan kematian (Departemen Kesehatan RI, 2013). Namun, pada umumnya daerah yang terkena bencana memiliki keterbatasan dalam aksesibilitas penyaluran makanan, pakaian, dan obat-obatan. Penyaluran obat-obatan di lokasi bencana merupakan salah satu tanggung jawab apoteker dalam penanganan bencana (Faradilla, 2018).

Manajemen penanggulangan bencana adalah segala upaya atau kegiatan yang dilaksanakan dalam rangka upaya pencegahan, mitigasi, kesiapsiagaan, tanggap darurat dan pemulihan berkaitan dengan bencana yang dilakukan pada tahapan sebelum, saat, dan setelah bencana (Faradilla, 2018). Menurut International Pharmaceutical Federation (FIP), (2006) mengeluarkan pernyataan profesional standar mengenai peran apoteker dalam menanggapi krisis, termasuk pandemi dan buatan manusia atau bencana alam (International Pharmaceutical Federation, 2006). Peran apoteker khususnya apoteker komunitas dalam penanggulangan bencana terdiri dari penanganan pra, saat, dan pasca bencana. Peran apoteker saat pra-bencana adalah memprediksi penyakit yang umum terjadi saat banjir, menyiapkan obat sesuai dengan prediksi penyakit, menyiapkan buffer stock di apotek terdekat dari wilayah langganan banjir, bekerja sama dengan tenaga kesehatan lain dengan membentuk ambulans keliling atau apotek bergerak (Bell dan Daniel, 2014). Saat terjadi bencana, apoteker beserta personelnya bertanggung jawab atas ketersediaan obat serta memastikan penggunaannya sudah tepat (Alkhalili, Ma, dan Grenier, 2017). Karena vitalnya peran apoteker terkait manajemen perbekalan kefarmasian pada masa bencana, maka diperlukan penelitian mengenai pengetahuan apoteker terkait perannya dalam penanganan bencana baik pra, saat, maupun pasca bencana. 


\section{METODE PENELITIAN}

Penelitian ini dilakukan dengan cara observasional dengan desain cross sectional yang bertujuan untuk mengetahui sejauh mana pemahaman apoteker khususnya apoteker di komunitas dalam penanganan bencana (sebelum, saat, dan setelah). Responden dalam penelitian ini adalah apoteker yang praktik di apotek wilayah Surabaya. Penelitian ini menggunakan teknik non-random sampling untuk memilih apotek yang digunakan sebagai tempat penelitian. Responden dalam penelitian ini berjumlah 265 responden. Terdapat 160 responden yang tidak bersedia untuk mengisi kuesioner. Oleh karena itu, hanya 105 responden yang mengisi kuesioner yang terdiri dari 104 kuesioner yang lengkap dan 1 kuesioner yang tidak lengkap. Sehingga, data responden pada penelitian ini adalah 104 responden.

\section{Instrumen Survei}

Kuesioner dirancang berdasarkan studi literatur mengenai disaster management dan pemahaman seorang apoteker. Metode pengumpulan data yang digunakan adalah kuesioner dengan metode kombinasi yaitu kuesioner yang terdiri dari pertanyaan terbuka dan tertutup. Kuesioner terdiri dari identitas responden, pengetahuan peran apoteker saat terjadinya banjir (terdiri dari 10 pertanyaan tertutup), persiapan yang dilakukan apoteker saat terjadi bencana (terdiri dari 5 pertanyaan tertutup), kesediaan dan persiapan apotek dan apoteker pada bencana alam (terdiri dari 8 pertanyaan tertutup), dan kondisi apotek saat terjadi bencana (terdiri dari 4 pertanyaan terbuka). Sehingga, total pertanyaan pada kuesioner adalah 28 pertanyaan. Kuesioner menggunakan metode Guttman, tanggapan dari responden dicatat dalam bentuk jawaban tegas seperti "ya", "tidak". "pernah", dan "tidak pernah".

Kuesioner yang digunakan telah divalidasi sebelum dilakukan pengambilan data di lapangan dengan melibatkan mahasiswa profesi apoteker Fakultas Farmasi Universitas Airlangga yang baru saja menyelesaikan studinya, yaitu dengan responden sebanyak 30 orang.

Data dikumpulkan melalui kuesioner yang diisi langsung oleh responden. Kuesioner diberikan kepada responden yaitu seorang apoteker yang berpraktik di apotek Surabaya. Ada sebanyak 265 apotek didatangi. Responden juga diberikan informasi tentang latar belakang survei dan tujuan penelitian sebelum mengisi kuesioner.

Data hasil pengetahuan apoteker dianalisis menggunakan skoring. Skor kurang (0-3), cukup (4-6), dan baik (7-9) pada masing-masing pertanyaan. Data demografi dalam bentuk tabel dan distribusi data ditampilkan secara persentase dan frekuensi. Pengolahan data dilakukan dengan bantuan aplikasi Statistical Package Software for the Social Sciences (SPSS) versi 21.0.

\section{HASIL DAN PEMBAHASAN}

Pentingnya peran apoteker dalam penanggulangan bencana tidak dapat dihindari. Untuk itu, dilakukan penelitian yang bertujuan untuk mengetahui pemahaman apoteker khususnya apoteker di komunitas dalam penanganan bencana (sebelum, saat, dan setelah). Jumlah responden pada penelitian ini adalah 104 responden. Berdasarkan analisis data hasil kuesioner Tabel 2 menunjukkan bahwa mayoritas apoteker dikategorikan baik karena memiliki pengetahuan yang baik terkait peran apoteker saat terjadi bencana. Responden dalam penelitian ini adalah apoteker yang praktik di apotek wilayah Surabaya Pusat, Timur, Selatan, Utara, dan Barat. Berdasarkan pada Tabel 1, mayoritas responden merupakan apoteker di Apotek swasta, kemudian Apotek Jaringan, dan paling sedikit adalah Apotek BUMN. Penelitian ini menggunakan teknik non-random sampling untuk memilih apotek yang digunakan sebagai tempat penelitian. Kelebihan dari penelitian ini yaitu penelitian pertama yang dilakukan di Surabaya untuk mengetahui pengetahuan dan peran apoteker tentang disaster management.

\section{Demografi Responden}

Peraturan Menteri Kesehatan Nomor 1332/MENKES/PER/X/2002 menyatakan bahwa adanya pengaturan pemberian izin apotek bertujuan untuk meningkatkan kualitas pelayanan kefarmasian di apotek. Apoteker dapat mendirikan apotek dengan modal sendiri dan/ atau modal dari pemilik modal baik perorangan maupun perusahaan. Apoteker yang mendirikan apotek dengan bekerjasama dengan pemiliki modal maka pekerjaan kefarmasian harus tetap dilakukan sepenuhnya oleh apoteker (Permenkes, 2002). Kerjasama antara apoteker dengan pemilik modal apotek dibedakan menjadi dua yaitu apoteker yang ikut menyertakan modal dan apoteker yang tidak ikut menyertakan modal. Kepemilikan apotek yang hanya memikirkan keuntungan akan bertentangan dengan kepentingan apoteker 
penanggung jawab. Hal tersebut memungkinkan peran apoteker penanggung jawab di Apotek menjadi kurang optimal jika terdapat kepentingan yang bertentangan. Sampel yang digunakan pada fase survei ini adalah 104 responden. Mayoritas responden adalah perempuan $(n=95 ; 91,35 \%)$ dengan pendidikan S1 Apoteker yang bekerja di apotek swasta. Lama bekerja rata-rata responden adalah sebesar 5 tahun. Selain itu, dari 104 responden, $20,19 \%$ dari responden yang telah mengisi kuesioner menyatakan sering mengalami banjir disekitar daerah tempat tinggal atau di tempat praktik Apoteker.

Tabel 1. Demografi responden $(\mathrm{n}=104)$

\begin{tabular}{lll}
\hline \hline Data & & $\mathrm{n}(\%) / \mathrm{Mean}$ \\
\hline Umur & 22-69 tahun & $31,7 \pm 10,0$ \\
\hline \multirow{2}{*}{ Jenis kelamin } & Laki-laki & $9(8,65)$ \\
\cline { 2 - 3 } & Perempuan & $95(91,35)$ \\
\hline \multirow{2}{*}{ enis apotek } & Swasta & $58(55,77)$ \\
\cline { 2 - 3 } & Jaringan & $28(26,92)$ \\
\cline { 2 - 3 } & BUMN & $18(17,31)$ \\
\hline Pendidikan & S1 & $100(96,15)$ \\
\cline { 2 - 3 } & S2 & $3(2,88)$ \\
\cline { 2 - 3 } & S3 & $1(0,96)$ \\
\hline Lama bekerja dalam tahun & $5,1342 \pm$ \\
\multicolumn{2}{l}{$\begin{array}{l}\text { Bencana yang sering terjadi pada } \\
\text { daerah sekitar }\end{array}$} & $21(20,19)$ \\
tempat tinggal & apotek atau & \\
\hline \hline
\end{tabular}

\section{Pengetahuan Apoteker Terhadap Peran Farmasi saat Terjadinya Bencana}

Hasil analisis data kuesioner digunakan untuk melihat pemahaman apoteker terhadap perannya saat terjadi bencana. Data hasil kuesioner oleh 104 apoteker dari 265 Apotek yang ada di Surabaya tentang pelayanan standar penanggulangan bencana yang ditunjukkan oleh Tabel 9 menunjukkan bahwa sebanyak 92,3\% apoteker dapat menjamin keamanan dan keselamatan staf farmasi lainnya bila terjadi bencana di waktu kerja, 91,34\% apoteker dapat mengatur dan menjamin stok kebutuhan obat di apotek untuk persiapan bencana, 96,15\% apoteker dapat menyediakan obat yang dibutuhkan di tempat terjadinya bencana, 96,15\% apoteker melakukan konseling kepada korban bencana, 93,27\% apoteker dapat mengantisipasi adanya perubahan penyakit, seluruh apoteker menjamin keamanan dan penyimpanan obat di tempat bencana (100\%), 94,23\% apoteker menyediakan berbagai kebutuhan obat dan alat kesehatan pada berbagai tahap penanganan bencana, 75,96\% apoteker menjamin pasien agar tidak terinfeksi penyakit dan 95,19\% apoteker menetapkan prosedur agar aktivitas di apotek tetap berjalan meskipun terjadi bencana.

Selain peran apoteker, terdapat pertanyaan untuk melihat sejauh mana apoteker mengetahui dan memahami praktik kefarmasian dari segi kode etik, seperti memberikan diagnosis pada pasien di daerah terdampak bencana yang harusnya menjadi tugas tenaga kesehatan lain (dokter) (ASHP, 2003). Berdasarkan hasil penelitian pada Tabel 2, maka pengetahuan apoteker dapat dikategorikan menjadi 3 yaitu baik $(41,3 \%)$, cukup $(55,8 \%)$, dan kurang $(2,9 \%)$. Hal ini menunjukkan bahwa sebagian besar apoteker memiliki pengetahuan yang cukup mengenai peran apoteker saat terjadi bencana.

Tabel 2. Kategori pengetahuan apoteker saat terjadi bencana

\begin{tabular}{ll}
\hline \multicolumn{1}{c}{$\begin{array}{c}\text { Pengetahuan apoteker terhadap } \\
\text { disaster management }\end{array}$} & $\mathrm{n}(\%)$ \\
\hline Kurang & $3(2,9)$ \\
\hline Cukup & $58(55,8)$ \\
\hline Baik & $43(41,3)$ \\
\hline \hline
\end{tabular}

\section{Persiapan yang Dilakukan Apoteker saat Terjadi Bencana}

Selain pengetahuan, terdapat hal lain yang juga penting dimiliki apoteker dalam menanggulangi bencana, yaitu persiapan. Persiapan yang dilakukan apoteker menentukan apakah apoteker tersebut mampu mengatasi permasalahan saat bencana terjadi dengan baik, cukup baik, atau kurang baik.

Tabel 3. Persiapan Apoteker saat Terjadi Bencana

\begin{tabular}{lcc}
\hline \multirow{1}{*}{ Pernyataan } & \multicolumn{2}{c}{ Pilihan } \\
\cline { 2 - 3 } & $\mathrm{na}$ & Tidak \\
\cline { 2 - 3 } & $\mathrm{n}(\%)$ & $\mathrm{n}(\%)$ \\
\hline $\begin{array}{l}\text { Anda mengikuti kegiatan } \\
\text { pelatihan terkait } \\
\text { penanggulangan bencana }\end{array}$ & $(21,15)$ & $(78,85)$ \\
\hline $\begin{array}{l}\text { Anda melakukan perencanaan } \\
\text { tentang perancangan alur }\end{array}$ & 27 & 77 \\
$\begin{array}{l}\text { informasi kebutuhan obat di } \\
\text { daerah terdampak bencana }\end{array}$ & $(25,96)$ & $(74,04)$ \\
\hline $\begin{array}{l}\text { BNPB bertanggungjawab } \\
\text { terhadap peninjauan terhadap } \\
\text { rencana penanggulangan } \\
\text { bencana terkait penyakit dan } \\
\text { obat yang dibutuhkan }\end{array}$ & $(42,31)$ & $(57,69)$ \\
\hline $\begin{array}{l}\text { Pemerintah yang melakukan } \\
\text { kerjasama dengan industri } \\
\text { farmasi atau distributor obat } \\
\text { untuk pemesanan serta } \\
\text { pendistribusian obat dan alat } \\
\text { kesehatan saat terjadi bencana }\end{array}$ & & \\
\hline $\begin{array}{l}\text { Anda menyiapkan obat-obat } \\
\text { khusus untuk penyakit kronik } \\
\text { saat terjadi bencana }\end{array}$ & & \\
\hline \hline
\end{tabular}


Berdasarkan Tabel 3, hanya terdapat 22 apoteker $(21,15 \%)$ dari total responden yang pernah mengikuti pelatihan terkait penanggulangan bencana dan hanya terdapat 77 apoteker $(74,04 \%)$ yang telah melakukan perencanaan tentang perancangan alur informasi serta hanya terdapat 47 apoteker $(45,19 \%)$ telah menyiapkan obat-obat khusus untuk penyakit kronik saat terjadi bencana. Berdasarkan data yang didapatkan, dapat disimpulkan bahwa meskipun apoteker mengetahui dan memahami perannya saat terjadi bencana, namun terdapat 82 apoteker $(78,85 \%)$ yang ternyata belum pernah mengikuti kegiatan pelatihan terkait penanggulangan bencana.

Oleh karena itu, dilakukan penggolongan tentang persiapan apoteker terhadap disaster managementuntuk mengetahui apakah apoteker mampu mengatasi permasalahan saat bencana terjadi. Penggolongan dibuat 3 kategori yaitu apoteker memiliki persiapan yang kurang, cukup, dan baik terhadap disaster management. Berdasarkan Tabel 4, dapat disimpulkan bahwa apoteker di Kota Surabaya memiliki persiapan yang cukup terhadap disaster management karena memiliki persentase terbesar yaitu $55,8 \%$.

Tabel 4. Kategori persiapan apoteker saat terjadi bencana

\begin{tabular}{ll}
\hline $\begin{array}{c}\text { Persiapan apoteker terhadap } \\
\text { disaster management }\end{array}$ & $\mathrm{n}(\%)$ \\
\hline Kurang & $3(2,9)$ \\
\hline Cukup & $58(55,8)$ \\
\hline Baik & $43(41,3)$ \\
\hline \hline
\end{tabular}

Kesediaan dan Persiapan Apotek dan Apoteker Pada Bencana Alam

Dalam persiapan dan kesediaan apoteker pada penanggulangan bencana, apoteker bertugas dalam penyediaan obat dan alat kesehatan serta melakukan konseling pada pasien atau korban yang terdampak bencana. Berdasarkan Tabel 5, dalam pelayanan standar penanggulangan bencana, dapat dilihat bahwa sebagian besar apoteker sudah memahami pentingnya kesediaan dan persiapan apotek serta apoteker pada saat terjadinya bencana. Selain menyediakan obat, alat kesehatan dan memberikan konseling, apoteker juga berperan dalam memetakan penyakit yang diderita oleh korban sehingga dapat meminimalisir penyebaran penyakit menular pasca bencana terutama saat terjadi bencana banjir. Apotek dan apoteker tidak harus berdiri sendiri untuk berpartisipasi dalam penyediaan obat dan alat kesehatan saat terjadinya bencana, apotek dan apoteker dapat bekerja sama dengan institusi lain dalam memperhitungkan, menyediakan, serta mendistribusikan obat dan alat kesehatan yang dibutuhkan di pengungsian dengan harapan bahwa obat yang didapatkan lebih banyak dan proses pendistribusiannya lebih merata serta menyeluruh kepada korban. Berdasarkan hasil survei tentang kesediaan maupun persiapan apotek dan apoteker saat terjadi bencana alam dapat diketahui bahwa sebagian besar telah siap serta bersedia dalam menyediakan obat dan alat kesehatan saat bencana. Kesiapan dan kesediaan apotek dapat dilihat bahwa sebagian banyak apotek menyediakan obat dan alat kesehatan yang dibutuhkan saat bencana, selain itu apotek dan apoteker juga mendistribusikan obat dan alat kesehatan yang diperlukan ke daerah bencana.

Tabel 5. Kesediaan serta Persiapan Apotek dan Apoteker pada Bencana Alam

\begin{tabular}{|c|c|c|}
\hline \multirow[t]{3}{*}{ Pernyataan } & \multicolumn{2}{|c|}{ Pilihan } \\
\hline & $\mathrm{Ya}$ & Tidak \\
\hline & $\mathrm{n}(\%)$ & $\mathrm{n}(\%)$ \\
\hline $\begin{array}{l}\text { Apoteker harus selalu siap di } \\
\text { tempat pengungsian saat } \\
\text { terjadi banjir }\end{array}$ & $\begin{array}{c}79 \\
(75.96)\end{array}$ & $\begin{array}{c}25 \\
(24.04)\end{array}$ \\
\hline $\begin{array}{l}\text { Apoteker wajib mencegah } \\
\text { tersebarnya penyakit menular }\end{array}$ & $\begin{array}{c}97 \\
(93.27)\end{array}$ & $7(6.73)$ \\
\hline $\begin{array}{l}\text { Dengan banyaknya pasien } \\
\text { pada saat banjir, apoteker } \\
\text { harus tetap melakukan } \\
\text { konseling untuk setiap } \\
\text { pasiennya }\end{array}$ & $\begin{array}{c}100 \\
(96.15)\end{array}$ & $4(3.85)$ \\
\hline $\begin{array}{l}\text { Apoteker perlu survey } \\
\text { pemetaan penyakit yang } \\
\text { sedang diderita oleh korban } \\
\text { banjir }\end{array}$ & $\begin{array}{c}90 \\
(86.54)\end{array}$ & $\begin{array}{c}14 \\
(13.46)\end{array}$ \\
\hline $\begin{array}{l}\text { Apotek menyediakan obat- } \\
\text { obatan dan alat kesehatan } \\
\text { untuk bencana banjir di } \\
\text { daerah tersebut }\end{array}$ & $\begin{array}{c}102 \\
(98.08)\end{array}$ & $2(1.92)$ \\
\hline $\begin{array}{l}\text { Apotek bekerjasama dengan } \\
\text { institusi lain terkait } \\
\text { penyediaan obat untuk } \\
\text { korban bencana banjir di } \\
\text { daerah tersebut }\end{array}$ & $\begin{array}{c}92 \\
(88.46)\end{array}$ & $\begin{array}{c}12 \\
(11.54)\end{array}$ \\
\hline $\begin{array}{l}\text { Apotek harus menghitung } \\
\text { stok obat dan alkes yang } \\
\text { dibutuhkan untuk bencana }\end{array}$ & $\begin{array}{c}101 \\
(97.12)\end{array}$ & $3(2.82)$ \\
\hline $\begin{array}{l}\text { Apotek perlu } \\
\text { mendistribusikan obat untuk } \\
\text { bencana banjir di daerah } \\
\text { tersebut }\end{array}$ & $\begin{array}{c}96 \\
(92.31)\end{array}$ & $8(7.69)$ \\
\hline
\end{tabular}

\section{Kondisi Apotek saat Terjadi Bencana}

Hasil analisis data kuesioner digunakan untuk melihat pemahaman apoteker terhadap perannya saat terjadi bencana. Pada penelitian ini juga diteliti terkait bencana yang sering 
terjadi dan kesiapsiagaan apoteker ketika terjadi bencana alam di Surabaya. Berdasarkan Tabel 6, bencana banjir merupakan bencana yang sering terjadi di Kota Surabaya, yakni sekitar $58,8 \%$. Hal ini disebabkan Kota Surabaya merupakan kawasan yang terletak di hilir sebuah daerah aliran sungai Brantas yang bermuara di Selat Madura. Selain itu, beberapa sungai besar yang berasal dari hulu mengalir melintasi Kota Surabaya, yaitu Kali Surabaya, Kali Mas, Kali Jagir, dan Kali Lamong.

Tabel 6. Kondisi Bencana yang Sering Terjadi di Sekitar Apoteker Secara Keseluruhan di kota Surabaya

\begin{tabular}{clll}
\hline \hline No & Jenis Bencana & $\begin{array}{l}\text { Jumlah } \\
\text { responden }\end{array}$ & $\%$ \\
\hline 1 & Kebakaran & 18 & 17,65 \\
\hline 2 & Banjir & 62 & 58,8 \\
\hline 3 & Gempa Bumi & 1 & 0,85 \\
\hline 4 & Lain lain & 23 & 22,7 \\
\hline \hline
\end{tabular}

Sebagai daerah hilir, Kota Surabaya merupakan daerah limpahan debit air dari sungai yang melintas sehingga rawan banjir pada musim penghujan. Di samping itu Kota Surabaya diidentifikasi sebagai wilayah yang rawan genangan air dari limpahan debit air sungai dan saluran pada musim penghujan serta banjir rob khususnya wilayah pesisir pantai Surabaya Utara (Perwali Surabaya, 2018) sehingga menyebabkan berbagai macam penyakit yang diderita oleh masyarakat ketika bencana alam berlangsung.

Terdapat berbagai macam penyakit yang sering terjadi pada saat bencana alam, antara lain diare, pusing, mual, batuk, pilek, tifus, demam, dan gatal-gatal. Berdasarkan Tabel 7 menyatakan bahwa penyakit diare merupakan penyakit yang sering dialami oleh warga Surabaya ketika terjadi bencana alam. Hal ini dikarenakan mayoritas bencana alam yang ada di Surabaya adalah banjir. Bencana banjir dapat menyebabkan diare karena sumber air minum masyarakat, khususnya sumber air minum dari sumur dangkal akan ikut tercemar sehingga menyebabkan diare (Suryani, 2013). Sehingga, diperlukan suatu persiapan yang dilakukan apoteker dalam hal penanganan bencana alam.
Tabel 7. Penyakit yang sering muncul ketika Terjadi bencana

\begin{tabular}{llll}
\hline \hline No & Jenis Penyakit & Jumlah responden & $\%$ \\
\hline 1 & Diare & 55 & 52,48 \\
\hline 2 & Pusiang & 19 & 18,44 \\
\hline 3 & Mual & 14 & 13,48 \\
\hline 4 & Lain lain & 16 & 15,6 \\
\hline \hline
\end{tabular}

Berdasarkan dari Tabel 5 menyatakan bahwa tingkat kesediaan apotek dalam menyiapkan obat dan alat kesehatan untuk penanggulangan bencana sebanyak $98.08 \%$. Adapun obat dan alat kesehatan yang disiapkan untuk menanggulangi bencana adalah attapulgit, kotak P3K, masker, kursi roda, Non Steroid Anti Inflammation Drug (NSAID), obat ISPA, alkohol, minyak gosok, salep gatal, termometer, handsaplast, dan tensimeter. Hal ini didukung oleh data pada Tabel 8 yang menyatakan bahwa apoteker sebagian besar menyiapakan obat diare pada saat bencana alam di Surabaya, yakni sebesar 57\%. Hal ini dikarenakan Surabaya merupakan salah satu kota yang mempunyai prevalensi yang tinggi terhadap penyakti diare, yakni sekitar 50.000 kejadian selama tahun 2017 (Asedha, 2017) dan termasuk kota yang rawan terjadinya banjir dikarenakan kondisi geografisnya.

Tabel 8. Obat yang disediakan Apotek pada Saat Terjadinya Bencana

\begin{tabular}{llll}
\hline \hline No & Obat & Jumlah responden & $\%$ \\
\hline 1 & Diare & 59 & 57 \\
\hline 2 & ISPA & 28 & 27,3 \\
\hline 3 & Vaksin & 2 & 1,8 \\
\hline 4 & Lain lain & 15 & 13,9 \\
\hline \hline
\end{tabular}

Pada penelitian ini terdapat keterbatasan, yakni menggunakan teknik non-random sampling sehingga, diperkirakan masih belum bisa menggambarkan pengetahuan apoteker di Kota Surabaya.

\section{KESIMPULAN}

Berdasarkan penelitian yang telah dilakukan terhadap apoteker di Kota Surabaya mengenai pengetahuan dan peran apoteker dalam disaster management, maka dapat disimpulkan bahwa apoteker dalam penelitian ini memiliki pengetahuan yang baik dan sudah siap dan tanggap terhadap bencana alam yang sewaktu-waktu dapat terjadi. Hal ini terbukti dari 
Tabel 9. Tingkat Pengetahuan Peran Farmasi saat Terjadinya Bencana

\begin{tabular}{llcc}
\hline No & & \multicolumn{2}{c}{ Pilihan } \\
& & \multicolumn{1}{c}{ Pernyataan } & Tidak \\
\cline { 2 - 3 } & & $\mathrm{n}(\%)$ & $\mathrm{n}(\%)$ \\
\hline 1. & $\begin{array}{l}\text { Apoteker harus dapat menjamin keamanan dan keselamatan staf farmasi } \\
\text { lainnya bila terjadi banjir di waktu kerja }\end{array}$ & $96(92,3)$ & $8(7,7)$ \\
\hline 2. & $\begin{array}{l}\text { Apoteker mengatur dan menjamin stok kebutuhan obat di apotek untuk } \\
\text { persiapan bencana }\end{array}$ & $95(91,34)$ & $9(8,66)$ \\
\hline 3. & $\begin{array}{l}\text { Apoteker menyediakan obat yang dibutuhkan sesuai data kebutuhan di } \\
\text { tempat terjadinya bencana }\end{array}$ & 100 & $4(3,85)$ \\
\hline 4. & $\begin{array}{l}\text { Apoteker melakukan konseling pada masyarakat/korban bencana terkait } \\
\text { efektivitas dan keamanan obat saat terjadi bencana }\end{array}$ & 100 & $4(3,85)$ \\
\hline 5. & $\begin{array}{l}\text { Apoteker dapat melakukan diagnose penyakit yang diderita korban } \\
\text { bencana }\end{array}$ & $20(19,23)$ & $84(80,77)$ \\
\hline 6. & $\begin{array}{l}\text { Apoteker mampu mengantisipasi adanya perubahan penyakit atau luka } \\
\text { dan mencari obat serta alat kesehatan yang sesuai untuk penanganan hal } \\
\text { tersebut }\end{array}$ & $97(93,27)$ & $7(6,73)$ \\
\hline 7. & $\begin{array}{l}\text { Apoteker menjamin keamanan dan penyimpanan obat yang sesuai di } \\
\text { pusat distribusi obat }\end{array}$ & $104(100)$ & $0(0,0)$ \\
\hline 8. & $\begin{array}{l}\text { Apoteker menyediakan berbagai kebutuhan obat dan alat kesehatan } \\
\text { pada berbagai tahap penanganan bencana, misalnya banjir }\end{array}$ & $98(94,23)$ & $6(5,77)$ \\
\hline 9. & $\begin{array}{l}\text { Apoteker menjamin pasien yang datang ke tempat praktiknya agar tidak } \\
\text { terinfeksi penyakit yang ada saat terjadi bencana }\end{array}$ & $79(75,96)$ & $25(24,04)$ \\
\hline 10. & $\begin{array}{l}\text { Apoteker menetapkan prosedur agar aktivitas di apotek tetap berjalan } \\
\text { meskipun terjadi bencana di daerah sekitar. }\end{array}$ & $99(95,19)$ & $5(4,81)$ \\
\hline
\end{tabular}

tingginya persentase peran apoteker dalam disaster management. Namun, apoteker di Surabaya mempunyai tingkat partisipasi yang rendah ketika diadakannya pelatihan terkait disaster management. Hal Ini terbukti dengan rendahnya keterlibatan apoteker dalam mengikuti kegiatan pelatihan atau seminarmengenai disaster management. Selain itu, pentingnya mengatasi permasalahan di bidang pengobatan, seperti pendistribusian dan penyimpanan obat-obatan ketika bencana alam terjadi merupakan tantangan bagi tenaga kesehatan, salah satunya apoteker. Maka dari itu, untuk meningkatkan kemampuan apoteker dalam disaster management, apoteker disarankan mengikuti pelatihan tentang disaster management serta mengikuti kegiatan sosial, agar pengetahuan dan kemampuan apoteker dalam disaster management menjadi lebih baik.

\section{UCAPAN TERIMA KASIH}

Kelompok 1 kelas A Farmasi Masyarakat Fakultas Farmasi Universitas Airlangga angkatan 2016 mengucapkan terima kasih kepada Ibu apt. Elida Zairina, S.Si., MPH., Ph. D., selaku dosen pembimbing, responden, serta semua pihak yang terlibat atas dukungan penuh selama melakukan penelitian ini.

\section{DAFTAR PUSTAKA}

Alkhalili, M., Ma, J., dan Grenier, S., 2017. Defining Roles for Pharmacy Personnel in Disaster Response and Emergency Preparedness: Disaster Med Public Health Prep, Vol 11, No.4, p 496-504.

American Society of Health-System Pharmacist, 2003. ASHP Guideline on Pharmacist Conducted Patient Education and Conducted Patient Education and Conseling, Am. J. Health-Syst. Pharm.

Anonim, 2016. Geografis Surabaya. Diakses dari

https://surabaya.go.id/uploads/attachme nts/2017/12/40252/bab_1_geografis da ta_statistik_2016.pdf, pada tanggal 21 Agustus 2019

Asedha, F. R., 2019. Distribusi Daerah Bencana Kekeringan Kritis dengan Kejadian Penyakit Diare di Provinsi Jawa Timur Tahun 2017. Jurnal Berkala Epidemiologi, Vol 7, pp. 60-67.

Bell, C., and Daniel, S., 2014. Director's Forum: Pharmacy Leader's Role in Hospital Emergency Preparedness Planning. Hosp Pharm, Vol. 49, No. 4, p 398-404.

Bima Winardo, A., \& Fariza, A, 2010. Investigasi Daerah Rawan Banjir Di Kota Surabaya Dengan Menggunakan 
Metode Fuzzy. EEPIS Final Project. p 1-9.

Cann, K. F., Thomas, D. R., Salmon, R. L., Wyn-Jones, A. P., \& Kay, D, 2013. Extreme water-related weather events and waterborne disease. Epidemiology \& Infection, Vol. 141, No.4, p 671686.

Departemen Kesehatan Kesehatan Republik Indonesia, 2002. Keputusan Menteri Kesehatan Indonesia Nomor 1332/MENKES/PER/X/2002 tentang Perubahan atas Peraturan Menteri Kesehatan Republik Indonesia Nomor. 922/MENKES/PER/X/1993 tentang Ketentuan dan Tata Cara Pemberian Izin Apotik. Jakarta : Direktorat Jendral Pelayanan Kefarmasian dan Alat Kesehatan Departemen Kesehatan Republik Indonesia.

Departemen Kesehatan RI, 2013. Waspadai Tujuh Penyakit Musim Banjir. Jakarta: Depkes RI., Diakses dari http://www.depkes.go.id/article/view/2 200/waspadai-tujuh penyakitmusim-banjir.html, pada tanggal 21 Agustus 2019, Surabaya.

Faradilla, M., 2018. Peran Tenaga Kefarmasian dalam Penanggulangan Bencana Role of Pharmacist in Disaster Management: Pharmaceutical Sciences and Research, Vol. 5 No. 1, p 14-18.

International Pharmaceutical Federation (FIP), 2006. Statement of Professional Standards The Role Of The
Pharmacist In Crisis Management: Including Manmade And Natural Disasters And Pandemics. Netherlands.

Martin, J.D., 2018. Indonesia Disaster Management Reference Handbook. US: The Center forExcellence in Disaster Management and Humanitarian Assistance. p. 12-16

Peraturan Walikota Surabaya Nomor 31 Tahun 2018 tentang Perubahan Rencana Kerja Pemerintah Daerah (RKPD) Kota Surabaya Tahun 2018, 2018. Surabaya

Pirsaheb, M., Sharafi, K., Ahmadi, E., \& Moradi, M, 2017. Prevalence of the waterborne diseases (diarrhea, dysentery, typhoid, and hepatitis A) in West of Iran during 5 years (20062010). Annals of Tropical Medicine and Public Health, Vol. 10, No. 6, p. 1524.

Rosyidie, A, 2013. Banjir: Fakta dan Dampaknya, Serta Pengaruh dari Perubahan Guna Lahan. Journal of Regional And City Planning, Vol. 24, No. 3, p 241-249.

Suryani, A.S., 2013. Mewaspadai Potensi Penyakit Pascabanjir. Info Singkat Kesejahteraan Sosial, Vol 5, No. 3 pp. 3-6

Undang-Undang Republik Indonesia Nomor 24 Tahun 2007 tentang Penanggulangan Bencana, 2007. Jakarta 